\title{
PKM MENINGKATKAN KEMAMPUAN HARD SKILLS GURU PEMBELAJAR JURUSAN BISNIS DARING DAN PEMASARAN MELALUI PEMBUATAN WEB-BLOG SEBAGAI KOMPETENSI PEMASARAN ONLINE, SMKN 1 DAN SMK KOSGORO 2 KOTA PAYAKUMBUH
}

\author{
Rose Rahmidani $^{1)}$, Armiati $^{2)}$, Dessi Susanti ${ }^{3)}$ \\ ${ }^{1,2,3)}$ Universitas Negeri Padang \\ e-mail: rose_rahmidani@fe.unp.ac.id
}

\begin{abstract}
Abstrak
Kegiatan pengabdian masyarakat ini bertujuan meningkatkan hardskill guru-guru Jurusan Bisnis Daring dan Pemasaran di SMKN 1 dan SMK Kosgoro 2 kota Payakumbuh dalam hal: a) merancang pembuatan website. b) merancang prosedur Pemasaran On-line dengan menggunakan/ memanfaatkan $e$-mail dan Media Sosial. c) melakukan pemasaran melalui situs mobile. d) membuat Blog. Peserta yang mengikuti pelatihan ini berjumlah 20 orang guru-guru jurusan bisnis daring dan pemasaran online SMKN 1 dan SMK Kosgoro 2 Payakumbuh. Metode dan pendekatan yang digunakan adalah ceramah dan tanya jawab untuk menyampaikan materi yang bersifat teoritis tentang pemasaran Online dan memasarkan produk menggunakan website dan Blog. Serta Metode latihan dan bimbingan individual terkait dengan pengimplementasian atau praktek membuat Website dan Blog. Metode resitasi atau pemberian tugas yang dilakukan untuk mengetahui sejauh mana kemampuan peserta. Hasil dari kegiatan pengabdian ini adalah : 1) Meningkatnya kompetensi guru dalam merancang pembuatan website. Ukuran peningkatan ini dapat dilihat dari 85\% guru-guru SMKN 1 dan SMK Kosgoro 2 Kota Payakumbuh dapat menghasilkan website. 2) Meningkatnya kompetensi guru dalam merancang prosedur Pemasaran On-line dengan menggunakan/memanfaatkan e-mail dan Media Sosial. Ukuran peningkatan ini dapat dilihat dari 85\% guruguru SMKN 1 dan SMK Kosgoro 2 Kota Payakumbuh dapat merancang prosedur Pemasaran On-line dengan menggunakan/memanfaatkan e-mail dan Media Sosial. 3) Meningkatnya kompetensi guru dalam melakukan pemasaran melalui situs mobile.Ukuran peningkatan ini dapat dilihat dari 85\% guru-guru SMKN 1 dan SMK Kosgoro 2 Kota Payakumbuh dapat melakukan pemasaran melalui situs mobile. 4) Meningkatnya kompetensi guru dalam membuat Blog. Ukuran peningkatan ini dapat dilihat dari 85\% guru-guru SMKN 1 dan SMK Kosgoro 2 Kota Payakumbuh dapat membuat Blog.
\end{abstract}

Kata Kunci : Pemasaran Online, Situs mobile, Website, Blog

\section{PENDAHULUAN}

Sekolah Menengah Kejuruan (SMK) adalah bentuk pendidikan formal di Indonesia yang bertujuan menghasilkan tenaga kerja terampil sesuai dengan kompetensinya. Oleh karena itu, setelah tamat dari SMK lulusannya diharapkan siap untuk memasuki lapangan kerja sebagai tenaga kerja atau berwirausaha dan melanjutkan pendidikan ke jenjang yang lebih tinggi. Jurusan Bisnis Daring dan Pemasaran termasuk dalam salah satu kompetensi keahlian yang ada di SMK. Kegiatan belajar mengajar di Sekolah Menengah Kejuruan (SMK) saat ini berpedoman pada kurikulum 2013, meskipun masih ada yang memakai kurikulum tahun 2006 yaitu Kurikulum Tingkat Satuan Pendidikan (KTSP). Pada kurikulum 2013 SMK untuk Jurusan Bisnis Daring dan Pemasaran terdapat beberapa mata pelajaran baru sebagai bentuk penyesuaian terhadap dinamisasi kebutuhan Dunia Usaha dan Dunia Industri serta mengikuti perkembangan ilmu pengetahuan dan teknologi. Melalui muatan Kurikulum 2013 ini, untuk Jurusan Bisnis Daring dan Pemasaran, setidaknya ada tiga sasaran yang dicapai, yaitu mendidik dan mempersiapkan siswa untuk: (1) Berprofesi sebagai tenaga penjual pada perusahaan ritel baik sebagai pramuniaga maupun kasir, (2) Berprofesi sebagai tenaga penjual yang melayani penjualan langsung, dan (3) Berprofesi sebagai pelaku pemasaran online.

Melihat perkembangan bisnis dengan menggunakan internet mendorong siswa jurusan Bisnis Daring dan Pemasaran agar tidak hanya mempelajari pemasaran secara offline akan tetapi juga harus mempelajari pemasaran secara online. 
Pemasaran online atau E-Marketing menurut Ahmadi \& Hermawan (2013:186) adalah bagian dari E-business yang memanfaatkan media elektronik untuk melakukan aktivitas marketing dalam upaya mencapai tujuan marketing. Hal ini pula yang membuat pemasaran online wajib diajarkan di SMK jurusan Bisnis Daring dan Pemasaran di kelas X dengan kode kompetensi C2 dan dilanjutkan dengan materi bisnis online pada kelas XI. Mengenai pentingnya program tersebut, penelitian dari Spiller \& Tuten (2015:120) mendapati fakta bahwa dalam program pemasaran digital, siswa dapat berpartisipasi dalam menghadapi tantangan pemasaran online.

Mata pelajaran Pemasaran Online merupakan salah satu mata pelajaran produktif baru yang tertuang pada kurikulum 2013 untuk SMK yang memberikan bekal dasar pengetahuan bagi siswa dalam memahami cara melakukan pemasaran online. Pembelajaran pemasaran online yang diajarkan kepada siswa diharapkan mampu meningkatkan minat siswa untuk memulai dan mengembangkan usaha baik secara off-line maupun online agar siswa mempunyai keyakinan dan kepercayaan diri dalam memulai dan mengembangkan usaha dan tidak bergantung pada orang lain. Pembelajaran pemasaran online memberikan pengetahuan dan pelatihan kepada siswa bagaimana caranya memanfaatkan sistem online dalam pemasaran produk atau jasa. Penelitian oleh Erfianto dkk (2015:54) mengatakan bahwa "Siswa yang menggunakan teknologi dan sistem informasi dapat mendorong sikap dan perilaku untuk menjadi wirausahawan yang berbisnis secara online. Hasil penelitian Millman et.al (2010) mengatakan bahwa disiplin ilmu dengan pengetahuan dan keterampilan terkait IT berpengaruh terhadap minat berwirausaha online siswa. Sehingga dimungkinkan pembelajaran pemasaran dengan menggunakan IT dapat mendorong minat siswa berwirausaha online.

Kompetensi Pemasaran Online membahas semua materi terkait dengan membuka peluang bagi para pelaku usaha untuk mengembangkan kegiatan bisnis melalui media elektronik. Sebagian besar pelajaran pemasaran online merupakan kegiatan bisnis yang dilakukan dalam jaringan internet yang merupakan bagian dari e-business. Perkembangan teknologi informasi memunculkan berbagai jenis kegiatan yang berbasis pada teknologi informasi, seperti e-government, e-commerce, e-education dan lainnya. Sebagai contoh perkembangan teknologi informasi dalam bidang pendidikan (e-education) adalah banyaknya Sekolah Menengah yang memiliki jaringan internet.

Fakta ini membuktikan bahwa dunia pendidikan dituntut untuk dapat mengikuti perkembangan teknologi informasi. Perkembangan teknologi informasi yang begitu cepat ini secara otomatis menuntut peningkatan kualitas sumber daya tenaga pendidik dalam bidang teknologi informasi. Walaupun banyak sekolah telah mempunyai perangkat teknologi informasi, namun pemanfaatan perangkat teknologi informasi itu masih belum maksimal. Kemampuan guru dalam menggunakan perangkat teknologi informasi, seperti: penggunaan program- program aplikasi dalam komputer, pemanfaatan teknologi internet dan sebagainya masih tergolong rendah. Termasuk pada aktivitas guru dalam mengajarkan Kompetensi Pemasaran Online. Pada bagian materi tentang pemasaran online diperlukan media pembelajaran berbasis web berupa latihan atau praktek.Tetapi untuk materi tersebut diperlukan metode dan media yang berbeda untuk memberikan variasi dan kemudahan dalam memahami materi tersebut (Kurniasih dan Setiawan, 2013: 22). Pada saat ini pembelajaran Pemasaran Online masih menggunakan media sosial seperti facebook, BBM, Whatsapp sehingga belum optimal dalam pengelolaan pembelajaran pemasaran onlinenya.

Kondisi ini tentunya berdampak kepada kualitas pembelajaran yang dilaksanakan oleh guru di dalam kelas. Rendahnya kemampuan guru dalam pemanfaatan teknologi informasi, berdampak pula kepada rendahnya hasil belajar siswa. Berdasarkan pengamatan yang dilakukan pada SMKN 1 dan SMK Kosgoro 2 Kota Payakumbuh dan hasil wawancara pengusul dengan ketua Jurusan Bisnis Daring dan Pemasaran pada kedua sekolah diperoleh informasi masih rendahnya kompetensi siswa Jurusan Bisnis Daring dan Pemasaran untuk mata pelajaran bisnis online. Hal ini dikarenakan masih rendahnya kempetensi guru-guru mata pelajaran produktif dalam mengajarkan materi tersebut. Hal 
ini dipicu karena pada umumnya guru-guru pada jurusan ini tidak memiliki keahlian dalam menggunakan Teknologi Informasi seperti pembuatan website dan blog. Dari 12 orang guru keahlian Bisnis dan Manajemen di SMK 1 Kota Payakumbuh hanya 1 orang guru yang bisa mengajarkan materi Pemasaran online. Itupun dengan kompetensi yang belum optimal sehingga siswa yang seharusnya setelah mempelajari materi pemasaran online diharapkan memiliki kompetensi membuat blog atau web sendiri, tetapi sampai saat ini belum ada satu orangpun siswa yang mampu mempraktekkannya.

Hal serupa juga ditemukan pada guru-guru di SMK Kosgoro 2 Payakumbuh yang memiliki 5 orang guru mata pelajaran produktif pada jurusan Bisnis Daring dan Pemasaran. Hanya 1 orang guru yang bisa mengajarkan materi pemasaran online dengan segala keterbatasan kompetensi yang dimilikinya. Jika guru tersebut tidak bisa hadir karena ada sesuatu hal maka guru lain tidak bisa menggantikan mengajarkan materi pemasaran online ini karena mereka tidak memiliki kompetensi untuk penguasaan materi ini dan mengajarkannya kepada siswa.

Kondisi ini tentunya mempengaruhi proses pembelajaran yang dilakukan oleh guru di kelas. Aktivitas pembelajaran yang seharusnya dilaksanakan dengan cara praktek memanfaatkan teknologi informasi tersebut, pada umumnya dilakukan dengan ceramah yang tentu saja pembelajaran yang dilaksanakan menjadi tidak menarik. Walaupun kegiatan praktek dilakukan di labor pemasaran, namun guru tidak mampu menghadirkan pembelajaran yang dituntut oleh tujuan pembelajaran yaitu "siswa mampu merancang pembuatan website dan blog". Bila gurunya tidak memiliki pengetahuan dan keterampilan ini, tentu saja tidak bisa membuat siswanya juga memiliki kompetensi yang diharapkan.

Adapun sarana yang dibutuhkan untuk mempelajari pemasaran online yaitu komputer dan jaringan internet. Fasilitas di laboratorium kedua sekolah sudah memadai yang dapat dilihat dari foto di atas. Sementara itu hampir $100 \%$ guru sudah memilikinya secara pribadi juga sudah memiliki sarana itu, yaitu laptop dan modem atau menggunakan jaringan internet dari sekolah. Namun penggunaan internet di kalangan guru masih terbatas pada fungsi pencarian dan pengayaan materi pembelajaran.

Berdasarkan uraian di atas, maka peningkatan kompetensi sangat perlu dilakukan oleh setiap guru mata pelajaran Pemasaran Online dalam rangka meningkatkan kualitas pembelajaran yang pada akhirnya menghasilkan siswa yang kompeten dalam bidang pemasaran online. Guna memfasilitasi kebutuhan guru pemasaran untuk peningkatan kompetensi khususnya mata pelajaran Pemasaran Online, maka diperlukan suatu pendidikan dan latihan pemasaran online tingkat dasar dan tingkat lanjut.

Berdasarkan permasalahan di atas penulis dan tim sepakat untuk menindaklanjuti permasalahan yang dihadapi oleh guru-guru jurusan bisnis daring dan pemasaran SMKN 1 dan SMK Kosgoro 2 Payakumbuh dengan melakukan kegiatan pengabdian pada masyarakat dengan judul "PKM Meningkatkan Kemampuan Hardskill Guru Pembelajar Jurusan Bisnis Daring dan Pemasaran Melalui Pembuatan WEB-BLOG Sebagai Kompetensi Pemasaran Online, SMKN 1 dan SMK Kosgoro 2 Kota Payakumbuh".

Tujuan kegiatan pengabdian masyarakat ini adalah: a) Memberikan pelatihan dan workshop kepada guru-guru Jurusan Bisnis Daring dan Pemasaran di SMKN 1 dan SMK Kosgoro 2 Payakumbuh. dalam merancang pembuatan website. b) memberikan pelatihan dan workshop kepada guru-guru Jurusan Bisnis Daring dan Pemasaran di SMKN 1 dan SMK Kosgoro 2 Payakumbuh. dalam merancang prosedur Pemasaran On-line dengan menggunakan/memanfaatkan e-mail dan Media Sosial, c) memberikan pelatihan dan workshop kepada guru-guru Jurusan Bisnis Daring dan Pemasaran di SMKN 1 dan SMK Kosgoro 2 Payakumbuh. untuk melakukan pemasaran melalui situs mobile. d) memberikan pelatihan dan workshop kepada guru-guru Jurusan Bisnis Daring dan Pemasaran di SMKN 1 dan SMK Kosgoro 2 Payakumbuh membuat Blog. 


\section{METODE KEGIATAN}

Agar tujuan dapat tercapai secara maksimal, maka dalam pelaksanaan pelatihan digunakan metode dan pendekatan yang bervariasi, yaitu sebagai berikut:

1. Metode ceramah dan tanya jawab untuk menyampaikan materi yang bersifat teoritis tentang pemasaran Online dan memasarkan produk menggunakan website dan Blog.

2. Metode latihan dan bimbingan individual terkait dengan pengimplementasian atau praktek membuat Website dan Blog.

3. Metode resitasi atau pemberian tugas yang dilakukan untuk mengetahui sejauh mana kemampuan peserta.

Langkah-langkah untuk merealisasikan kegiatan ini adalah :

\section{Tahap Persiapan}

Tahap persiapan yang dilakukan untuk melaksanakan program ini meliputi;

a. Pemantapan jadwal yaitu penentuan jadwal bersama mitra setelah usulan kegiatan disetujui untuk dilaksanakan.

b. Koordinasi dengan semua pihak yang terkait yang dalam hal ini yaitu sekolah mitra untuk pengurusan izin pelaksanaan kegiatan.

c. Penetapan peserta: penetapan peserta dilakukan bekerjasama dengan Kepala Sekolah Mitra. Jumlah peserta yang dilibatkan dalam pelatihan maksimal 20 orang.

d. Menghubungi instruktur dan pembicara dan menyesuaikan jadwal pelaksanaan.

e. Memperbanyak modul yang dibuat instruktur dan pembicara untuk dibagikan kepada peserta.

2. Tahap Pelaksanaan Kegiatan

Kegiatan di lokasi mitra dilaksanakan sebanyak dua hari. Sebelum memasuki ruangan, peserta dibekali dengan satu set ATK (Alat Tulis Kantor) untuk lebih memaksimalkan pelatihan. Dalam pelaksanaan kegiatan ini peserta akan diberi modul tentang pemasaran onlineyang disusun oleh pembicara. Kegiatan ini akan dibagi menjadi beberapa tahapan, yaitu:

a. Pelatihan dan workshop mengenai konsep pemasaran online. b. Pelatihan dan workshop merancang pembuatan website.

c. Pelatihan dan workshop mengoperasikan mesin pencari dengan memanfaatkan Search Engine Optimazation (SEO).

d. Pelatihan dan workshop merancang prosedur Pemasaran On-line dengan menggunakan/memanfaatkan e-mail dan Media Sosial.

e. Pelatihan dan workshop melakukan pemasaran melalui situs mobile.

f. Pelatihan dan workshop membuat Blog.

3. Tahap akhir

Pada tahap ini dilakukan kegiatan observasi dan evaluasi untuk mengukur keberhasilan kegiatan. Hasil kegiatan pelatihan menunjukkan tingkat keberhasilan dengan indikasi adanya : 1) Kesesuaian materi dengan kebutuhan guru-guru, 2) Respon yang positif dari guru-guru, dan sebagian besar (85\%) guru telah mampu; (a) melaksanakan konsep pemasaran online, (b) merancang pembuatan website, (c) mengoperasikan mesin pencari dengan memanfaatkan Search Engine Optimazation (SEO), (d) merancang prosedur Pemasaran Online dengan menggunakan/ memanfaatkan $e$ mail dan Media Sosial, (e) melakukan pemasaran melalui situs mobile, dan (f) membuat Blog yang merupakan kompetensi yang harus diajarkan pada mata pelajaran Pemasaran Online.

\section{HASIL DAN PEMBAHASAN}

Sebelum kegiatan dilaksanakan, tim pelaksana mengunjungi SMKN 1 dan SMK Kosgoro 2 Payakumbuh. untuk membuat perencanaan tentang pelaksanaan kegiatan pelatihan ini. Kegiatan perencanaan dilakukan tim bersama dengan Kepala sekolah, wakil kepala sekolah serta guru mata pelajaran produktif pada jurusan Bisnis Daring dan Pemasaran. Pada kesempatan ini, disepakati beberapa hal yaitu; jadwal kegiatan, peserta kegiatan, serta teknis pelaksanaan kegiatan.

Kegiatan ini diikuti oleh 20 orang peserta dari guru-guru Jurusan Bisnis Daring dan Pemasaran di SMKN 1 dan SMK Kosgoro 2 Payakumbuh. 
Pelaksanaan pelatihan secara tatap muka bersama seluruh peserta berlangsung pada hari Jumat dan Sabtu tanggal 28-29 September 2018.

Bentuk kegiatan yang dilakukan adalah menyampaikan materi yang bersifat teoritis tentang pemasaran Online dan memasarkan produk menggunakan website dan Blog, memberikan latihan dan bimbingan individual terkait dengan pengimplementasian atau praktek membuat Website dan Blog serta pemberian tugas yang dilakukan untuk mengetahui sejauh mana kemampuan peserta.

Kegiatan pelatihan di awali dengan sarapan pagi bersama antara panitia pelaksana, peserta dan nara sumber. Tepat jam 9.00 Wib kegiatan pengabdian masyarakat dimulai dan diawali dengan acara pembukaan yang oleh Ibu Kepala Sekolah SMKN 1 Payakumbuh. Ibu kepala sekolah menyampaikan apresiasi karena dengan adanya kegiatan ini dapat membantu permasalahan yang dihadapi oleh sekolah terkait dengan meningkatkan kompetensi guru-guru jurusan bisnis daring dan pemasaran untuk menguasai materi pemasaran Online.

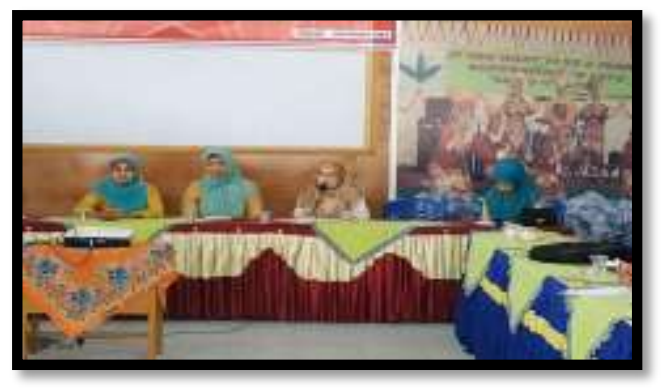

Gambar 1.

Pembukaan acara pengabdian masyarakat oleh Kepala Sekolah SMKN 1 Payakumbuh

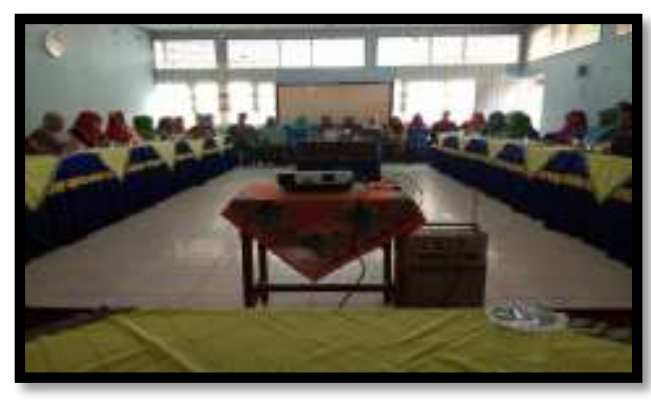

Gambar 2

Acara pembukaan dihadiri oleh peserta yang merupakan guru MGMP Jurusan bisnis daring dan pemasaran kota Payakumbuh

Setelah acara pembukaan kegiatan dilanjutkan dengan pelaksanaan kegiatan inti yaitu penyajian materi secara teoritis. Adapun materi pertama disampaikan oleh Ibu Yunita Engraini, SE, MM yaitu tentang Konsep Pemasaran Online. Pemateri menjelaskan tentang manfaat pemasaran Online diantaranya pebisnis dapat melakukan penyesuaian terhadap kondisi pasar dengan cepat, pemasar online dapat berbicara dengan pelanggan dan dapat mengetahui berapa banyak pelanggan yang mengunjungi situs mereka. Walaupun banyak manfaat pemasaran Online bagi pebisnis tapi masih banyak pelaku bisnis yang enggan untuk melakukan pemasaran Online. Hal ini disebabkan karena berbagai faktor diantaranya kurang menguasai teknologi pembuatan Web (Dianawati, A, 2008). Pada penyampaian materi pertama ini juga dijelaskan tentang komponen pemasaran Online dan cara kerja pemasaran online.

Materi kedua dilanjutkan oleh Ibu Megawati, SE, MM. Materi yang disampaikan tentang Pengelolaan Website dan E-Commerce. Pada kesempatan ini pemateri menjelaskan tentang bagaimana kiat-kiat yang harus dilakukan untuk meningkatkan popularitas suatu Website diantaranya dengan cara memperbanyak artikel, meng update konten secara rutin dan konsisten, jangan mengcopy paste konten atau artikel, membuat konten yang viral dan mensubmit artikel ke socialbookmark yang populer. Pemateri juga menjelaskan strategi pemasaran Online menggunakan search engine. Bagi seorang pengusaha, tak terkecuali pelaku bisnis online, salesman yang hebat adalah merupakan ujung tombak pemasaran. Salesman harus mampu mendatangkan pembeli potensial yang melakukan pembelian terhadap barang atau jasa yang dijual. Pada pemasaran online, peran salesman terletak pada search engine, terutama Google dan Yahoo! yang merupakan dua search engine terpopuler di dunia. Search engine adalah salesman yang hebat dan tidak perlu dibayar. Strategi pemasaran online adalah menjadi nomor satu pada hasil pencarian search engine. Hanya dengan membuat website tidak akan membuat seorang pelaku bisnis online menjadi internet marketer sejati. Website dibuat dengan strategi khusus yang bertujuan untuk memenangkan persaingan pada search engine, sehingga suatu website akan mampu tampil setidaknya pada halaman pertama hasil pencarian search engine. 
(Anggraini, 2008). Search engine sangat mencintai content web yang relevan dengan produk yang dijual, yang disampaikan dengan bahasa yang lugas dan fokus. Untuk menjamin agar web dapat terindeks dengan baik pada pencarian, seorang pelaku bisnis online hanya perlu bermain-main dengan kata dan kalimat. Meski banyak cara untuk menempatkan posisi web pada pencarian teratas, namun content web adalah segalanya (Kurnia, R.A., 2008).

Pada penyampaian materi, nara sumber juga menjelaskan tentang kiat sukses E-Commerce. Diantaranya Membuat logo yang jelas, informasi login, pencarian dan keranjang belanja harus jelas, metode pembayaran harus jelas, disarankan menggunakan beberapa jenis pembayaran, menginformasikan kelebihan produk secara ringkas dan menampilkannya di beranda.

Kegiatan pengabdian masyarakat dilanjutkan pada hari Sabtu tanggal 29 September 2018. Kegiatan hari kedua ini dilaksanakan dengan kegiatan praktek membuat Website E-Commerce. Kegiatan ini dipandu oleh nara sumber yaitu Bapak Syukhri, S.T, M.CIO yang merupakan staff pengajar pada jurusan Teknik Elektronika UNP. Sebelum memulai praktek pemateri telah memberikan panduan untuk membuat website yang telah di import ke laptop masing-masing peserta. Kemudian peserta dipandu dalam merancang dan membuat Website sesuai dengan tahap-tahapannya. Pada kegiatan ini pemateri menjelaskan bahwa untuk saat sekarang pembuatan web bukanlah menjadi hal yang sulit karena kemajuan teknologi terutama di bidang perkembangan website. Salah satu yang bisa dimanfaatkan adalah CMS (Content Management System), dan salah satu CMS yang terkenal dan mudah untuk membuatnya adalah Wordpress, karena wordpress merupakan jenis website yang berbasis open source, sehingga banyak orang yang akan mengembangkan website jenis ini dan ini bisa menjadi reverensi yang baik bagi orang yang akan membuat website wordpress.

Dalam membuat website ada 2 komponen yang harus dipersiapkan yaitu domain dan web hosting. Domain adalah nama dan alamat dari sebuah website contohnya nama domain .co.cc dan Web Hosting adalah tempat meletakkan file -file website pada server yang terhubung dengan jaringan internet. Saat ini banyak sekali perusahaan di Indonesia maupun di luar negeri yang bergerak di bidang jasa pendaftaran domain dan penyediaan paket web hosting. Dengan tingkat persaingan yang ketat saat ini, sampaisampai ada beberapa perusahaan domain dan hosting yang memberikan layanannya secara gratis dan masyarakat dapat memanfaatkan hal tersebut untuk membuat website. Dengan biaya hampir nol, sebab biaya normal untuk pembelian domain kira-kira Rp.80.000,- per tahun dan untuk web hosting kirakira Rp. 360.000,- pertahun untuk paket pemula. Bila membuat website untuk kepentingan personal atau bisnis kecil, bisa mengambil domain dan web hosting gratis dan jIka membuat website untuk kepentingan bisnis besar, tentunya sebaiknya menggunakan domain dan web hosting yang berbayar, hal ini dikarenakan dengan kebutuhan spesifikasi web hosting yang diberikan untuk menunjang kebutuhan website. Setelah mempersiapkan domain dan hosting, langkah selanjutnya baru membuat website.

Para peserta di tugaskan untuk membuat website masing-masing dilengkapi dengan informasi yang jelas tentang produk-produk yang di jual. Misalnya dilengkapi dengan foto dan harga jualnya.

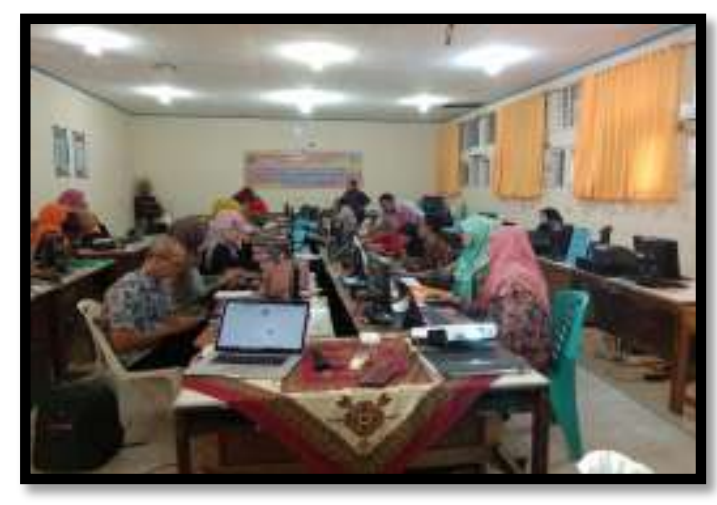

Gambar 3. Peserta kegiatan antusias dan serius mengikuti kegiatan PKM

Pelaksanaan kegiatan pelatihan ini berjalan dengan baik dan lancar. Hal ini diketahui dari antusiasme yang ditunjukkan oleh peserta karena mendapatkan pengetahuan dan keterampilan baru dalam hal membuat website. Melalui kegiatan ini dapat membantu guru meningkatkan kompetensinya untuk membuat website sehingga merekapun bisa mengajarkannya kepada siswa. 
Di penghujung waktu kegiatan berakhir dilakukan kegiatan penutupan, dimana kegiatan ini langsung ditutup oleh Ibu Kepala SMKN 1 Payakumbuh. Beliau sangat mengapresiasi kegiatan ini karena sangat bermanfaat bagi guru Ucapan terima kasih disampaikannya kepada tim sekaligus kepada Universitas Negeri Padang yang telah memilih sekolah mereka sebagai tempat dilakukannya kegiatan ini.

\section{KESIMPULAN}

Kesimpulan dari kegiatan pengabdian masyarakat ini adalah:

1. Pengetahuan dan pemahaman peserta pelatihan yang terdiri dari guru SMKN 1 dan SMK Kosgoro 2 Payakumbuh Jurusan Bisnis Daring dan Pemasaran tentang pengelolaan Website menjadi bertambah.

2. Keterampilan dan kompetensi peserta dalam merancang dan membuat website meningkat sehingga mampu mengajarkan kepada pesera didik di kelas dan menggunakannya dalam pemasaran secara online.

3. Kegiatan pelatihan ini berjalan dengan sukses dan lancar karena mendapatkan dukungan dari banyak pihak. Kepala Sekolah SMKN 1 dan SMK Kosgoro 2 Payakumbuh sangat mensupport kegiatan ini karena dapat menambah skill guruguru jurusan bisnis daring dan pemasaran dalam menambah kompetensi membuat website.

4. Peserta kegiatan PKM memiliki motivasi yang tinggi dan sangat antusias mengikuti pelatihan dan workshop sehingga komit untuk menggunakan web yang sudah dirancang sebagai media promosi dalam menjalankan bisnis.

Berdasarkan evaluasi yang telah dilakukan dapat diajukan beberapa saran sebagai berikut:

1. Kegiatan lanjutan yang berupa pelatihan dan workshop sejenis selalu diselenggarakan secara periodik sehinga dapat meningkatkan kemampuan hardskill guru pembelajar dalam melaksanakan proses pembelajaran.
2. Melalui kegiatan pelatihan dan workshop ini, diharapkan guru-guru SMK Bisnis Manajemen Payakumbuh menerapkan ilmu dan skill yang diperoleh, sehingga menjadi guru pembelajar yang selalu memberikan kemampuan terbaiknya bagi peserta didik dalam rangka meningkatkan kualitas pembelajaran dan mencapai tujuan pendidikan.

3. Tindak lanjut oleh guru mata pelajaran khususnya dan sekolah umumnya untuk dapat menggunakan website yang telah di buat ini secara aktif terutama di gunakan dalam bisnis.

4. Mengadakan pelatihan serupa dengan teknik dan model yang berbeda serta khalayak sasaran yang berbeda pula serta wilayah jangkauan SMK yang lebih luas.

\section{REFERENSI}

Ahmadi, C \& Hermawan, D. (2013). E-Business \& E-Commerce. Yogyakarta: Penerbit Andi.

Anggraeni, Ari Andian. (2008). Manajemen Keyword: Strategi Pemasaran Online Menggunakan Search Engine .Jurnal Pendidikan Akuntansi Indonesia Vol. VI. No. 2 - Tahun 2008 Hal. 60 - 69.

Dianawati, A., 2008, "6 Rahasia Sukses Menjadi Jutawan Internet”, Mediakita, Jakarta.

Erfianto, D., Rahayu, W. P., \& Kusumajanto,D. D. (2015). Penerapan Blog Sebagai Media Pembelajaran Mata Pelajaran Pemasaran Online. Jurnal Pendidikan Bisnis dan Manajemen, 1 (1), 1- 70.

Kurnia, R.A., 2008, "Website yang Baik itu Memperindah Content, Bukan Desain!", (http://www.dibekasi.net/page _highlights.php?id_brt=55).

Millman, et al. (2010). Entrepreneurship Education and Students' Internet Entrepreneurship Intention. Journal of Small Business and Enterprise Development, 17 (4), 569- 590.

Spiller \& Tuten. (2015). Integrating Metrics Across the Marketing Curriculum: The Digital and Social Media Opportunity. Journal of Marketing Education, 37 (2),114-126. 